\title{
The Extent of Adoption of Islamic Work Ethics for Retail Trade in Palestine from the Point of View of their Customers
}

\author{
Dr. MAJEED MUSTAFA OTHMAN MANSOUR \\ Associate prof. Marketing, Arab American University Palestine. \\ Email: majeed.mansour@aaup.edu
}

\begin{abstract}
The study aimed at identifying the extent of adoption of Islamic work ethics for retail trade in Palestine from the point of view of their customers. The researcher selected a list of the retailers in Palestine, a stratified random sample of (322) retail customers was selected. The researcher developed a questionnaire as the main research tools. It consisted of a set of paragraphs examining the extent to which the retailers in Palestine adopts the ethics of Islamic work from the point of view of their customers. The results of the study indicate that there is a statistically significant correlation between the total degrees of retail trade in Palestine in relation to the commodity; furthermore, results indicate that there is a statistically significant negative correlation between (0.05) between the total score of the retail trade practices in Palestine and the Islamic work ethic. Based on the results of the study, the researcher made recommendations such as the necessity on the retailer's part abide by the ethical obligations of informing customers about the products, Clarity and accuracy in their relationship with customers, The retailer must avoid high-price practices for some goods to make the consumer fancy that they are of high quality, not to reduce the price of goods that are about to expire, and not to declare the price of the commodity to be higher than the real price.
\end{abstract}

Keywords: Retail, Islamic Work Ethics, Commodity, Consumer, Promotion.

\section{Introduction}

Retail is an activity that targets buyers directly and indirectly, so that the quantities of goods are small, the retailer is a real person or a company, and plays a mediator role between the buyer and the seller as the retailer buys the goods and resells them (Obaidat, 2011, P. 18). The retail trade involves many stages and processes that begins with getting the goods to be delivered to the consumer, which may include sales and services. These operations focus on a number of problems that start with the choice of the retail market and focus on it; and selecting the market (Arafa, 2010, p. 15).

Where the problem is buying goods and achieving a margin of profit on storage and put on the shelves to sell and identify the amount of revenue achieved for each item and brand during the year or more of the problems facing the retailer significantly, which requires planning the inventory so that the estimated number of days taken to convert the goods offered for sale or so-called cash flow cycle (Obaidat, 2011, p. $150)$.

The problem of retail communication is one of the tools retailers employ to attract more customers and buyers, which requires great effort in the organization's reputation and how to deal with the customer. This requires access to the selection of the best means for promotion, which contains a variety of problems such as choice of promotional means, and determination of the responsibility of this task (Obaidat, 2011, p. 180). Islamic work ethics is a concept of ethics that is based on Islamic teaching and principle which rely on faith. Meanwhile, organizational commitment is related to employees' attachment and behaviour towards the 
organization he works for. The study also found that Islamic work ethics affects organizational commitment and its three dimensions; affective, normative and continuance commitment (Salahudin, et al., 2016).

Linking the participation of retail practices and the system of Islamic business ethics is one of the most important modern issues. Serious attempts have been made to measure and implement them in light of the rapid economic, environmental and social changes at different levels of the world and the local community. This is reflected in the creative capabilities within the business organizations, which is the dividing line between success and failure. The foundation of creative capabilities important decisions are taken in determining the direction of the organization's progress and determining the degree of approach or distance from the goals. This will allow the management in general to develop its staff to benefit students and the outcomes of the management process and will help managers and employees learn how to develop their relationship to the benefit of them and their students as well as the sense of the manager and employee creative abilities. Therefore, the current study seeks to identify the role of retailers' practices and Islamic business ethics in enhancing the creative capabilities of Islamic banks in Palestine from the viewpoints of their employees. The ethical obligation in the retail activity represents a sentimental condition of the trader indicating his connection to his profession and trends towards it and his feeling that his values and objectives are in line with the values and objectives of the organization (Abdin, 2010).

\section{Research Problem}

The city of Tukaram is one of the largest Palestinian cities with a retail market covering a geographical area including Tulkarem and its villages. After reviewing the previous studies in the field of study, it is clear that previous studies dealt with the subject of retail practices separately from Any ethical standards of an Islamic nature, did not address the relationship between him and the ethics of Islamic work, and studies on the ethics of Islamic work dealt with different parts which did not take all aspects. What characterizes the current study is that it examines the subject in the context of the trade industry The Palestinian retail problem is a large and important sector in the Palestinian economy. Therefore, the problem of the study revolves around answering the following main question: How far does the retail trade in the Palestinian market affect the ethics of Islamic work?

\section{Study Questions}

The problem of the study is illustrated by the following questions:

- What are the practices of retailers in Palestine in terms of goods, price and distribution?

- What is the level of ethics of Islamic work among retailers in Palestine?

- What is the impact of Islamic business ethics on the practices of retailers in Palestine?

\section{Objectives of the study}

This study aims to achieve the following objectives:

- To identify the practices of retailers in Palestine in terms of goods, price and distribution.

- To identify the level of ethics of Islamic work among retailers in Palestine

- To understanding the impact of Islamic business ethics on the practices of retailers in Palestine.

\section{Study Hypotheses}

There is no significant statistical significance at the level of $(\alpha=0.05)$ for the ethics of Islamic work on the practices of retailers in Palestine. 


\section{Significance of the Study}

The current study is significant due to:

The current study is an important study that is important because it is a modern and qualitative study, especially since the topic was not written at the local or Arab level, as far as the researchers know, through previous researches and studies on the subject of the practices of retailers and the ethics of Islamic work. This study contributes to determining the levels of the role of retail practices and the ethics of Islamic work and strengthening the positive practices of the retailers in Palestine.

\section{The Scope of the Study}

The study is based on the first subject of the problems facing the retailers in the city of Tulkarem. The study is limited in its conceptual framework, methodology and concepts. The study will be limited to the practices of the retailers in Tulkarm, and its impact on the differences in Islamic work. The study will be limited to the collection of springs from retailers in the city of Tulkarem due to limited accuracy.

\section{Concepts of the Study and its Theoretical Framework}

The ethical obligation is a state of self-confidence in the individual, which indicates his attachment to his profession and his attitudes towards it and his feeling that his values and goals are consistent with the values and objectives of the institution. The study is determined in accordance with the arithmetic average of the responses of the study members to the questionnaire that determines the degree of performance of the teachers and their teachers the other side 's point of view (Abdin, 2010). The researchers defined it as a response to the sample of the study on the paragraphs and areas related to the moral obligation.

Salahudin et al., (2016) study found that the concept of business ethics and function is one of the old concepts that the Islamic religion has urged. History, traditions, traditions, national and national culture, tribal formation, the emergence of reference groups, leaders, political parties, the media and its development and the scientific and practical experience of society contribute to the formation of business ethics in any society (Amiri \& Al-Ghalbi, 2005, p. 134).

Ethics is a set of principles revolving around four main axes: to carry out targeted acts, not to harm others, not to be deceived in any dealings, and to be impartial in carrying out any practices in favour of one party without the other. If any activity in society is distinguished by these characteristics, the ethics of this function and activities are considered unethical (Abu Zaid \& Marai, 2004, p. 73).

The concept of business ethics has been linked to many topics, organizational tasks and human resources such as management, employees and managers. It guides and promotes good behaviour. Besides, this concept has become important for the job in the organization as it is confirmed by the administration because it is a self-censorship tool for the individual, because he can distinguish between right and wrong in his behaviour during work, and that is why Merry individuals with high work ethics in the organization on the grounds that these individuals are the ones who bring ethics or that the organization derives from the ethics of individuals where staff.

The science of ethics is the science that examines the moral values that relate to the acts of humanity in terms of good or evil. Moral behaviour is the behaviour that society adopts. This behaviour consists of a set of rules that show individuals how they should behave in situations where they are exposed without violating their consciences or custom in their community. A person's immoral behaviour is if he scratches a moral rule that is agreed upon by his community (Rashid \& Al-Hayadi, 2012). 
The "human development" is seen as the first source of the socio-economic structure of the nations through its real contributions to human beings, the enormous volume added to the stock of knowledge, and the theory of "human capital" The level of knowledge has increased, and therefore the levels of general national production have risen, which in turn is reflected in the increase in income levels of the people of the nations and the achievement of social welfare (Obaid, 2006).

Salahudin et al., (2016) stated that business ethics experienced many transformations to improve ethical behaviours and encouraging more transparency to avoid repetition of scandal and economic crisis. The concept of business ethics and function is one of the old concepts that the Islamic religion has urged. History, traditions, traditions, national and national culture, tribal formation, the emergence of reference groups, leaders, political parties, the media and its development and the scientific and practical experience of society contribute to the formation of business ethics in any society (Amiri \& Al-Ghalbi, 2005, p. 134).

Business ethics are a set of ethical principles and values that represent the behaviour of an organization and make determinants of its decisions. If we consider what we want to give a specific perception and definition of the ethics of work, we will find what he said is adequate for this purpose, where he pointed out that it applies to individual ethical standards in different business situations. There is also another definition previously mentioned that business ethics is only the systematic analysis and analysis of the processes through which the administrative decision is developed so that it becomes a moral choice taking into consideration what is true and good for the individual, groups and organization. The concept of business ethics is based on old concepts Which are urged by the Islamic religion. The ethics of the job are those charters and moral values of the workers during the exercise of their duties and duties of professional and professional while dealing with the beneficiaries of individuals, groups or organizations within the framework of responsibility and services available in the gulf Tama (Khatib, 2009).

Islamic work ethics are classified under divine command theory that uses religion as the foundation in identifying ethics. In Islamic study, right and wrong is clearly advocate through the word of Allah. Islamic perspective is more suitable in explaining ethics as it is comprehensive, moderate and realistic (al-Aidaros et al., 2013). One of the main rules in doing business in Islam is honesty and fairness in business transaction thus every businessman must be a person with strong ethical principles (Kaliffa, 2003). According to Suzuki (2014), Islam allows market's role and freedom in trade but at the same time control the freedom involving business and financial transaction based on number of prohibitions, ethics and norms.

Islamic ethics is a principle of right and wrong designated to demonstrate what human ought to do as taught in Quran and shown in the great life of Prophet Muhammad (Hashi, 2011). It views work as a way to promote self-interest economically, socially and psychologically in order to sustain social prestige, to increase societal welfare and reaffirm faith (Ali \& Al-Owaihan, 2008). Islam is a way of life that never takes apart every human activity from religion. Islamic law is based on four sources, in which two primary sources are the Quran and the Sunnah (examples set by Prophet Muhammad) while the other two are consensus of scholars (Ijmaa') and analogy (Qiyaas). Analogy is a derivation of a ruling of a new situation based on the analogy with a similar situation dealt with in Quran and/or hadith (Beekun \& badawi, 2005). Sunnah on the other hand is the way of life shown by Prophet Muhammad that can be used as a model and icon for human being and a well-known business. Ali and Al-Kazemi (2007) list down four issues that the Prophet had emphasized before; work as the highest form of worshipping Allah, work that is not performed in the best ability is not sanctioned, work must be for the benefits of others too as part of social dimension, and society can gain wealth and reasonable living standards by doing trade and business.

The concept of business ethics has been linked to many topics, organizational tasks and human resources such as management, employees and managers. It guides and promotes good behavior, and this concept has become important for the job in the organization as it is confirmed by the administration because it is a selfcensorship tool for the individual, because he can distinguish between right and wrong in his behavior during work, and that is why Merry individuals with high work ethics in the organization on the grounds 
that these individuals are the ones who bring her ethics or that the organization derives from the ethics of individuals where staff.

Today's organizations focus on the goals, principles, values and ethics of developing the performance of the individual employees, who are now the best resource of the organization's resources representing intellectual capital, focusing on them and building them spiritually and intellectually by providing them with knowledge, skills, abilities and behavior within the culture of the institution.

\section{Previous Studies}

Abdallah, (2010). Islamic Ethics: an exposure for resolving ICT ethical dilemmas. The aim of this study was to identify Islamic ethics and its role in the sharing of knowledge, Where the study shows that some of the standards of ethics in Islamic law and the ways in which the development of behaviours and ethical standards in individuals, where the study shows that the criteria derived from Islamic law on the concept of ethics in the work is based on a set of rules of jurisprudence that show the moral behaviour of others An example of these principles presented by the study is a rule that does not harm or harm that any action that harms individuals is immoral.

Yesil, Sekkeli and Dogan, (2012) An Investigation into the Implications of Islamic Work Ethic (IWE) in the Workplace. The study examined the principles and ethics of Islamic work and examined the extent of their similarity and differences from the Islamic work ethic to the work environment. The study also attempted to identify the relationship between the ethics of Islamic work and creative abilities. The study showed that Islamic work ethic enhances creative abilities, in addition to being different from other ethical standards in that it helps in determining the responsibilities of the individual and the organization clearly, showing their rights and duties They, in addition to increase their creative ability and consequent improvement in performance.

Lunis and Jagboub (2013) the aim of this study was to identify the management of time and its relation to the participation of knowledge and ethics of Islamic work among the secondary principals. A field study in Setif State. The aim of this study was to find out the relationship between time management and sharing of knowledge and ethics of Islamic work in secondary schools in Setif State for the academic year 2007/2008. (45) managers from the total of (54) managers at the level of the state of Setif using the first two measures measure the level of time management and the second to measure the degree of leadership innovation, was verified the validity of the measurements using the credibility of the arbitrators, By Alpha Crombach. The results were as follows: Principals have a good level of time management. There were no statistically significant differences in the level of time management among high school principals due to age. There were no statistically significant differences in the level of time management among high school principals attributed to gender. There were no statistically significant differences in the level of time management among high school principals due to the level of education. There were no statistically significant differences in the level of time management among high school principals due to experience. Senior managers have a good level of leadership innovation. There are no differences in the distribution of degrees of leadership innovation among high school principals due to age variable. There are no differences in the distribution of degrees of leadership innovation among high school principals due to gender variable. There are no differences in the distribution of degrees of leadership innovation among high school principals due to the variable level of education. There are no differences in the distribution of degrees of leadership innovation among high school principals due to the variable of experience. There is no statistically significant relationship between the level of time management and the degrees of leadership creativity among high school principals.

Study of the wheel and sea (2010) the aim of this study is to identify the extent to which the creative abilities of the staff managers in Gaza Strip ministries are available and their relation to their performance. The study is based on the descriptive approach. The study population consists of the managers of the 
ministries of the Gaza Strip (A4, A, B and C) and 1235 managers. The study questionnaire was designed as a means of collecting the necessary data. The sample was distributed to the sample of the study on a class basis. (82\%) of the original sample size using the SPSS statistical program and statistical tests were used (Pearson correlation coefficient - Alpha Kronbach test - $t$ test) and other tests in order to arrive at indications of value and indicators supporting the objective of the study. The ministries of the Gaza Strip have all the unique abilities of the highly creative person. Elements of good performance (professional skill, technical knowledge and general background of job requirements and related areas) are available to managers. Managers' performance is governed by controls that represent good performance standards. Evaluating the performance of the ministries of the Gaza Strip is routinely done without any real benefit to serve both the employee and the ministry.

Creation of an incubator for creativity or creation of the so-called "ideas bank". - Developing a strategy based on precise criteria for the detection of creative and talented people. - Decentralization, delegation of authority and participation of subordinates in decision-making. - Activation of the incentive system on the basis of professional standards, including excellence and creativity in performance and reward creators. Review the performance evaluation system to include objective and clear evaluation criteria, to ensure the employee to know the results of the calendar.

Mortensen and Amundsen conducted a study (2015) which was titled "Linking the leadership of creative empowerment with creative abilities and efforts of work and creativity: the course of self-leadership and psychological empowerment." The aim of this study was to link the sharing of knowledge and ethics of Islamic work and creative abilities. The study used descriptive analytical methods, the study shows that there is a positive correlation between creative abilities and creative abilities, since this relationship is considered positive and affects the work.

Razlan (2017) entitled "Local Retailers and Their Perspective on Social Responsibility," aimed at identifying social responsibility forms as practiced by local retailers in the United States, especially in small communities. The study also aimed to identify the motivations and benefits of practices Social responsibility in this segment of economic organizations.

The study used the quantitative approach and was conducted by a number of 20 retail establishments operating in the United States. The interview was used as a tool for collecting information from the study sample. The results of the study reached Retailers are active in their communities to provide in-kind and cash assistance. The motivation for these practices is the interest of retail organizations in the community in which they live, as well as to build reputation in communities and to reflect an appropriate mental image within small communities.

Sodhi and Tang (2017) entitled "The perspective of retailers on social responsibility. The study aimed to identify the role of small business chains and how they contribute to social responsibility in society. The study attempted to answer questions related to the inventory of social responsibility Retailers, the definition of the concept of poverty among retailers, and how retailers interact with their environment. The study showed that relatively small institutions that exist in small communities exercise a high level of social responsibility as a result of the affinity of members of the local community.

Nematollahi, Hosseini-Motlagh, and Heydari, (2017) entitled "Co-ordination of Social Responsibility Efforts in a Sample of Popular Business Chains and its Relationship to the Decision-Making Process". In the large commercial chains operating in the retail market, where the study was conducted in retail chains in Britain, and was conducted on two chains of stores that have large branches in the Kingdom. The study found that the patterns of social responsibility practices vary according to the decision-making style in the commercial chains Different between the strings that are centralization and decentralization in the management, as showed the results of the study that sellers that follow the style of decentralization where the level of social responsibility practices, greater and more appropriate to the local community in which it 
operates, and the results of the study that showed the practice of social responsibility increases the sales volume and goodwill.

Diddi, and Niehm, (2016), entitled "Social Responsibility in the Context of Retail Trade." The study aimed to examine the impact of consumers and customers and the personal impact on social responsibility practices. The study used the descriptive approach regarding a customer's approach in the global business establishments in the United States. The study revealed that customers are attracted to ethical practices issued by retailers, especially in large ones, and do what is expected by the environment and society in which they are active. The study also revealed that factors such as values Ethics, customs and traditions, and expectation $\mathrm{T}$ behavior, and knowledge of the surrounding environment and the trends towards society play a positive role in promoting social responsibility practices of retailers, especially in stores that carry distinctive brands.

The study examined the principles and ethics of Islamic work and examined the extent of their similarity and differences from the Islamic work ethic to the work environment. The study also attempted to identify the relationship between the ethics of Islamic work and creative abilities. The study showed that Islamic work ethic enhances creative abilities, in addition to being different from other ethical standards in that it helps in determining the responsibilities of the individual and the organization clearly, showing their rights and duties They, in addition to increase their creative ability and consequent improvement in performance.

Salahudin et al., (2016) devised structural model was constructed to test the effects of Islamic work ethics on organizational commitment. 156 respondents from randomly selected SMEs that involved in retail trade textile service located in Selangor, Kuala Lumpur and Johor were given six-point Likert scale questionnaire. The study found that the structural model is acceptable in term of validity and reliability thus can be used to measure the relationship between two variables. According to Al-Aidaros et al. (2013) Islamic work ethics is comprehensive, realistic and moderates. More recently, Islamic Work Ethics has been studied as moderating variables in Asian region (Tufail, Anum., Shahzad, \& Jehangir, 2018; Tufail, Shahzad, Gul, \& Khan, 2017) and is of great interest for researcher in Muslim countries. Ethics in islam is not only religious morality in certain acts but cover all facet of life either in physical, spiritual, moral or even in worldly form such as intellectual, emotional, individual and collective (Yaken, 2006).

\section{Method and Procedures}

Through this section, the researcher will identify the study community and its sample, construct the study tool, the steps to verify the validity of the tool and its stability, in addition to describing the variables of the study and the statistical methods used in analysing the data.

\section{Study Design}

The researcher used the analytical descriptive method to study the method of study, because it is suitable for the nature of the study, as it is a method based on the study of phenomena as it exists in reality, and it is expressed quantitatively in terms of the extent and size of the phenomenon. This method depends on collecting facts, data, classification, processing and analysis to draw their semantics and to reach conclusions or generalizations about the phenomenon under study.

\section{Study Population and Sample}

The society shall be of all retail trade in Palestine for the year 2016/2017. The researcher worked on a list of the names of retailers in Palestine, and was therefore chosen randomly, as shown in the following table: 
Table (1): Distribution of the sample of the study according to its independent variables

\begin{tabular}{llcc}
\hline \multicolumn{1}{c}{ Variable } & \multicolumn{1}{c}{ Level } & Frequency & \% \\
\hline \multirow{2}{*}{ Gender } & Male & 225 & 67.7 \\
Education level & Female & 119 & 32.3 \\
& Diploma & 37 & 5.0 \\
& B.A & 285 & 87.7 \\
Income level & M.A & 44 & 7.3 \\
& $4000-2000$ & 127 & 35.0 \\
& $6000-4001$ & 126 & 34.7 \\
Family number & +6001 & 113 & 30.3 \\
& $4-2$ & 82 & 20.0 \\
& $7-5$ & 172 & 50.0 \\
& 7 and more & 112 & 30.0 \\
Types of products & 125 & 34.3 \\
& Food commodities & 129 & 35.7 \\
& clothes and shoes & 74 & 17.3 \\
& Recreational services & 60 & 12.7 \\
& Telecommunications services & 322 & $\mathbf{3 2 2}$ \\
\hline
\end{tabular}

The survey shows that males accounted for $67.7 \%$ of the study sample. $87.7 \%$ of the study sample was bachelor's degree. It was found that one-third of the sample was 35\% of the monthly income (20004000) \% Of the study sample of households containing 5-7 persons, and 70\% work in food commodities, clothing and shoes.

\section{Study instrument}

The researcher developed the questionnaire as one of the research tools, consisting of a set of information requests, in order to collect information from the persons in question. The questionnaire is designed for statistical analysis of the answers. The questionnaire has standard answers that make it easy to collect and organize data (2006) and a review of research, studies and books that examined the extent to which the retail trade in Palestine adopted the ethics of Islamic work from the point of view of the study tool was made up of three parts:

Part 1: Includes preliminary information about the student who filled out the questionnaire.

The second part consisted of (30) paragraphs, distributed over different fields, and their vertebrae were responded to by the five-dimensional Likert balance. It starts at a very large scale and is given (5) Then the few are given two degrees, and ends with very little and is given only one degree.

\section{Validity}

In order to ascertain the Validity of the tool, it was presented to a group of specialized professionals in order to ascertain and comment on the paragraphs of the questionnaire and in terms of the formulation of their paragraphs and their suitability to the field for which they were established.

\section{Reliability}

The coefficient of Reliability of the instrument was extracted using the Cronbach's Alpha equation. Table (2) shows the stability coefficients of the instrument and its fields. 
Table (2): Reliability coefficients of the study instrument and its fields

\begin{tabular}{clccc}
\hline No. & & Domain & No. Items & Cronbach's Alpha \\
\hline 1 & Commodity & $\mathbf{4}$ & 0.71 \\
$\mathbf{2}$ & Price & $\mathbf{5}$ & 0.76 \\
$\mathbf{3}$ & Promotion & $\mathbf{9}$ & 0.72 \\
$\mathbf{4}$ & Distribution & $\mathbf{5}$ & 0.73 \\
$\mathbf{5}$ & Islamic Business Ethics & $\mathbf{7}$ & 0.78 \\
& Total score & 30 & 0.74 \\
\hline
\end{tabular}

It is clear from Table (2) that the total score of the areas of resolution was (0.77), in the total score, which are good stability coefficients and satisfy scientific research purposes.

\section{Study Procedures}

This study was carried out according to the following steps:

Prepare the questionnaire in its final form.

And then identify the sample members (study).

After the questionnaire was distributed to the study sample, it was retrieved.

The researcher coded the questionnaires and unloaded using the computer for the analysis and processing statistically using the statistical package for social sciences (SPSS).

After the data were entered into the computer, the results were extracted, analyzed and discussed, compared with previous studies, and suggested appropriate recommendations.

\section{Statistical Processes}

The researcher abstracted the answers of the sample and was encoded and entered using the computer. The data were processed statistically using the Statistical Package for Social Sciences (SPSS). The following statistical treatments were used:

To estimate the relative weight of the resolution paragraphs, frequencies, percentages, arithmetic averages and standard deviations were used;

To calculate the internal consistency of the study tool paragraphs, use the Alpha Cronbach's equation.

Finally, to examine the relationship between two variables, the Pearson correlation coefficient was used.

\section{Study Results}

In this chapter, the results of the study were presented according to the order of their questions and hypotheses.

First: Results related to the study question:

How far does retail trade in Palestine fit the ethics of Islamic business from the point of view of their customers?

The length of the cells of the five-dimensional Likert scale used in the study axes was calculated and the range $(5-1=4)$ was calculated and then divided by the number of cells of the scale to obtain the length of the cell $(4 / 5=0.80)$ and then this value was added to the lowest value in the scale (or beginning of the scale, the correct one); to determine the upper limit of this cell, thus the length of cells became as follows:

-From 1 to 1.80 represents (very low grade).

-from 1.81 to 2.60 represents (low grade).

-from 2.61 to 3.30 represents (middle grade). 
-from 3.41 to 4.20 represents (high score)

-From 4.21 to 5.00 represents (very high score).

Table (3): The arithmetical averages and standard deviations of the fields of study

\begin{tabular}{rlccc}
\hline $\begin{array}{r}\text { Item } \\
\text { No. }\end{array}$ & & $\begin{array}{c}\text { Item } \\
\text { Mean }\end{array}$ & SD & \% \\
\hline & $\begin{array}{l}\text { Commodity } \\
.1\end{array}$ & 3.3 & 0.40 & 66.5 \\
2 & $\begin{array}{l}\text { The information on the item's cover is unclear and accurate } \\
\text { without paying attention to the consumer's interest }\end{array}$ & 2.9 & 1.22 & 58 \\
& $\begin{array}{l}\text { The retailer purports to hide the country of origin of the commodity and } \\
\text { claim another country of origin. }\end{array}$ & 3.1 & 1.19 & 62 \\
.4 & $\begin{array}{l}\text { The goods are characterized by poor packing and packaging, resulting } \\
\text { in damage. }\end{array}$ & 3.5 & 0.78 & 70 \\
\hline
\end{tabular}

It is clear from the results of the study that the highest paragraphs in terms of degree of response were in paragraphs related to topics such as the fact that the information appearing on the cover of the commodity is not clear and accurate, and resort to the retailer to manipulate the validity of the commodity without regard to the interest, and that the retailer deliberately conceals the country of origin of the commodity and claims another country of origin, and that the goods are characterized by packaging and packaging which leads to damage.

Table (4): Statistical averages and standard deviations of the study fields

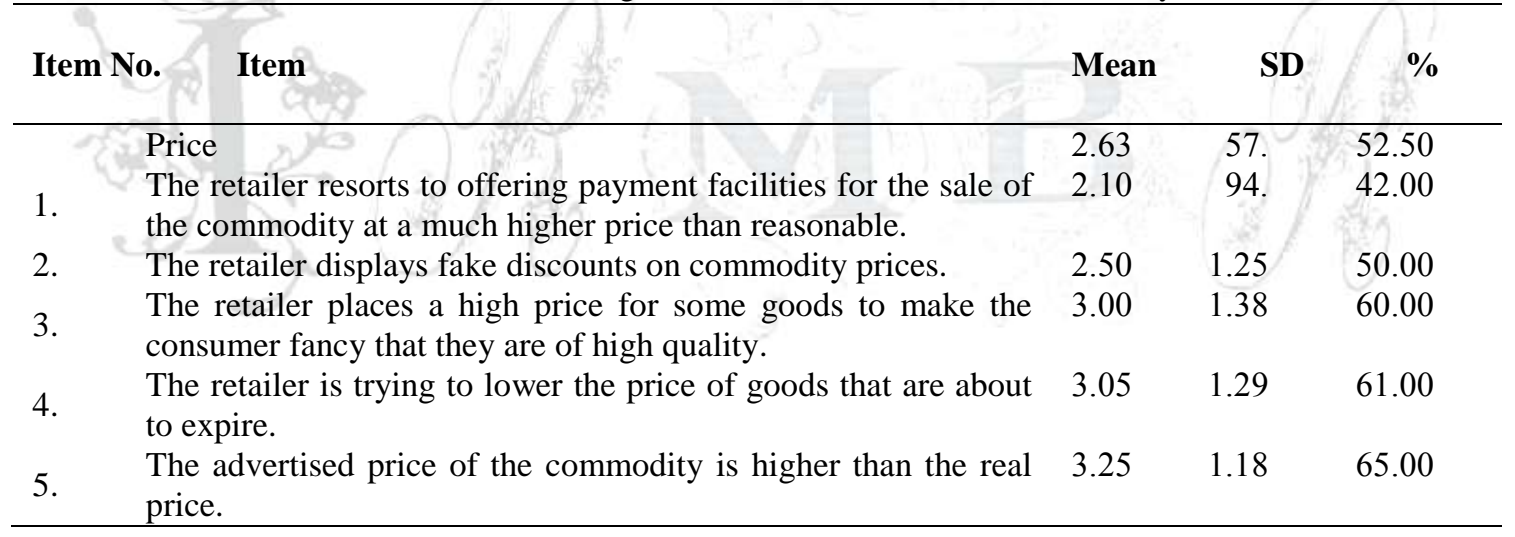

It is clear from the results of the study that the highest scores in terms of price response are in paragraphs relate to subjects such as placing the retailer a high price for some goods to make the consumer fancy that it is of high quality, goods that are about to expire, and the declared price of the commodity is higher than the real price.

It is clear from the results of the study that the highest paragraphs in terms of the degree of approval of the promotion field were in paragraphs which relate to the topics of packaging some products in large size to make the consumer fancy a large size product, And raise consumer fears and concerns through commercial advertising to push for purchase, and the retailer does not provide sufficient information on alternative goods to guide the consumer to a specific option. 
Table (5): Statistical averages and standard deviations of the study fields

\begin{tabular}{|c|c|c|c|c|}
\hline $\begin{array}{r}\text { Item } \\
\text { No. }\end{array}$ & Item & Mean & SD & $\%$ \\
\hline & Promotion & 2.74 & 56. & 54.83 \\
\hline .1 & $\begin{array}{l}\text { Retailer uses female sex in commercial advertising to influence } \\
\text { consumer buying decision. }\end{array}$ & 2.20 & 1.08 & 44.00 \\
\hline .2 & $\begin{array}{l}\text { The products are wrapped in an attractive and elegant manner in order to } \\
\text { hide the defects of the product. }\end{array}$ & 2.20 & 1.03 & 44.00 \\
\hline .3 & $\begin{array}{l}\text { The retailer tries to promote the item in various ways to get consumers } \\
\text { to buy it, regardless of need. }\end{array}$ & 2.70 & 1.42 & 54.00 \\
\hline .4 & $\begin{array}{l}\text { The retailer advertises fake goods for some goods to lure the consumer } \\
\text { to other goods. }\end{array}$ & 2.85 & 1.15 & 57.00 \\
\hline .5 & A retailer uses to advertise the item with misleading information. & 2.90 & 1.38 & 58.00 \\
\hline .6 & $\begin{array}{l}\text { Some of the products are wrapped in a large casing to make the } \\
\text { consumer fancy a large size item. }\end{array}$ & 3.00 & 1.14 & 60.00 \\
\hline .7 & The retailer will advertise the item with insufficient information. & 3.05 & 81. & 61.00 \\
\hline .8 & $\begin{array}{l}\text { The retailer resorts to consumer concerns and concerns through a } \\
\text { commercial advertisement for a purchase. }\end{array}$ & 3.25 & 1.00 & 65.00 \\
\hline .9 & $\begin{array}{l}\text { The retailer does not provide sufficient information about alternative } \\
\text { goods to direct the consumer to a specific option. }\end{array}$ & 3.45 & 87. & 69.00 \\
\hline & od ctond ond d loviotions of the ch & elds & & \\
\hline Item & & Mean & SD & $\%$ \\
\hline 2 & Distribution $0=0$ & 3.38 & .57 & 67.50 \\
\hline .1 & $\begin{array}{l}\text { The retailer places a high price on the commodity on the pretext of } \\
\text { bringing it from far away. }\end{array}$ & 3.10 & .83 & 62.00 \\
\hline .2 & $\begin{array}{l}\text { The retailer is trying to increase the prices of some commodities, claiming } \\
\text { that the price is higher than the source, which is not. }\end{array}$ & 3.55 & 1.03 & 71.00 \\
\hline .3 & $\begin{array}{l}\text { The retailer sells low-quality items at a high price because they are sold in } \\
\text { high-end stores. }\end{array}$ & 3.60 & .92 & 72.00 \\
\hline .4 & The retailer sheds strong lighting on some goods to look attractive and not. & 3.70 & 1.10 & 74.00 \\
\hline .5 & $\begin{array}{l}\text { The retailer displays the goods inside the store in a manner that suggests } \\
\text { luxury and is not. }\end{array}$ & 3.95 & .81 & 79.00 \\
\hline
\end{tabular}

It is clear from the results of the study that the highest paragraphs in terms of the degree of response in the distribution are in paragraphs which are related to the subjects put the retailer high price on the commodity on the pretext of bringing them from far away. The prices of some goods are claiming a higher price than the source, which is not. The retailer has put low quality goods at a high price because they are sold in high-end stores, the retailer sheds strong lighting on some goods to look attractive and it is not, in a way that suggests luxury and it is not.

It is clear from the results of the study that the areas of price, promotion and goods have received a low degree of response in the overall degree, while the areas of distribution and ethics of Islamic work has received a high response rate, and it is clear to the researcher that the reason these low averages to the nature of the fact that the retailer Can work with sufficient flexibility to make a profit, while the flexibility of the retailer in the areas of commodity pricing, promotion and commodity is considered low, and some methods to maneuver more in order to maximize profits, which is contrary to the ethics of Islamic work significantly. 


\begin{tabular}{|c|c|c|c|c|}
\hline $\begin{array}{r}\text { Item } \\
\text { No. }\end{array}$ & Item & Mean & SD & $\%$ \\
\hline & Islamic business Ethics: & 3.55 & 60. & 71.00 \\
\hline .1 & $\begin{array}{l}\text { Preserving the environment in the sense of not polluting the } \\
\text { environment with waste production }\end{array}$ & 3.40 & 1.24 & 68.00 \\
\hline .2 & Respect intellectual property rights & 3.45 & 1.03 & 69.00 \\
\hline .3 & Employees receive gifts only as permitted by regulations & 3.60 & 74. & 72.00 \\
\hline .4 & Theft or taking money from customers unlawfully. & 3.65 & 1.11 & 73.00 \\
\hline .5 & Cheating, deceit and lying in any kind and with any hand & 3.75 & 83. & 75.00 \\
\hline .6 & $\begin{array}{l}\text { Maintaining the safety and health of employees, the community and } \\
\text { customers. }\end{array}$ & 3.75 & 1.00 & 75.00 \\
\hline .7 & Use of information not available to the public for gains from trade & 3.85 & 1.02 & 77.00 \\
\hline
\end{tabular}

It is clear from the results of the study that the paragraphs that received the highest response in respect of the field of ethics of the Islamic factor were in the paragraphs that relate to topics such as theft or taking money from customers unlawfully, fraud and deception and lying of any kind and with any party, and maintain the safety and health of employees and society and customers, The use of information not available to the public to gain from trade.

\section{Results related to the hypothesis of the study:}

The hypothesis states: There is no statistically significant relationship at the level of significance $(0.05)$ between the retail trade practices in Palestine in terms of (commodity, price, promotion and distribution) with the ethics of Islamic work?

Table (7): Pearson correlation coefficient for the relationship between retail trade practices in Palestine in terms of (commodity, price, promotion and distribution) of Islamic business ethics.

\begin{tabular}{llc}
\hline \multirow{2}{*}{ Item } & & Islamic Business Ethics \\
\multirow{2}{*}{ Price } & Coefficient of correlation & $-.271-{ }^{* *}$ \\
& Level of significance & 0.000 \\
\multirow{2}{*}{ Promotion } & Coefficient of correlation & $-0.353^{* *}$ \\
& Level of significance & 0.000 \\
Distribution & Coefficient of correlation & $-0.41-^{* *}$ \\
& Level of significance & 0.000 \\
& Coefficient of correlation & $-0.119-{ }^{*}$ \\
& Level of significance & 0.040 \\
\hline
\end{tabular}

*statistically significance at $(\alpha=0.05)$.

The results of the study show that there is a statistically significant correlation between the total score of the retail trade in Palestine and the correlation coefficient (0.27). Which is statistically significant at the mean level (0.01).

The results of the study indicate that there is a statistically significant correlation between the total score of the retail trade in Palestine and the correlation coefficient value $(0.35)$. Which is statistically significant at the mean level.(0.01) The results of the study indicate that there is a statistically significant correlation between the total score of the retail trade in Palestine and the coefficient of correlation (0.43). Which is statistically significant at the mean level.(0.01). The results of the study showed a statistically significant correlation between the total score of the retail trade in Palestine and the correlation coefficient $(0.11)$. Which is statistically significant at the mean level.(0.01) 
Table (8): Pearson correlation coefficient for the relationship between retail practices in Palestine in terms of Islamic business ethics.

\begin{tabular}{llc}
\hline & & \multicolumn{2}{c}{$\begin{array}{l}\text { Islamic Business } \\
\text { Ethics }\end{array}$} \\
\hline Retail Practices & correlation Coefficient & $-.366^{* *}$ \\
& Level of significance & .000 \\
\hline
\end{tabular}

The results of the study indicate that there is a statistically significant correlation between the total score of the retail trade in Palestine and the Islamic work ethic, where the correlation coefficient value is 0.36 .

\begin{tabular}{ccccc}
\hline $\mathbf{R}$ & $\mathbf{R 2}$ & Adjusted R2 & T & sig \\
\hline $.366^{\mathrm{a}}$ & .134 & .131 & -6.798324 & $0.01^{*}$ \\
\hline
\end{tabular}

It is clear from the results of the study that the ethics of Islamic work explain only $13 \%$ of the retail practices in Palestine and Islamic work ethics, where the correlation coefficient value $(0.36)$ and the adjusted interpretation coefficient (0.13).

\section{Conclusions and Recommendations}

It is clear from the results of the study that the highest paragraphs in terms of the degree of response in the area of the product were in the paragraphs that relate to topics such as the fact that the information appearing on the cover of the item is not clear and accurate, and the resort of the retailer to manipulate the date of validity of the product without concern for the consumer, The country of origin of the commodity and the claim of another country of origin. And that the goods are characterized by packaging and packaging which leads to damage. thus consistent with previous research by Yousef (2000) and research by Othman et al., (2004). It proves that high Islamic work ethics will resulting high in organizational commitment and indicates that the implementation of Islamic work ethics can help achieving great commitment among employees towards the organization.

Jaros (2007) stated that affective commitment is an emotional bonds between employees and organization while from Islamic work ethics perspectives, emotional bonds are not only only developed towards the organization but also towards the society and mainly towards Allah, the Creator It is clear from the results of the study that the highest grades in terms of the degree of response in the price range are topics related to topics such as placing the retailer high price for some goods to make the consumer fancy that it is of high quality, and the retailer resort to reduce the prices of goods that are about to expire, The advertised price of the item is higher than the real price. It is clear from the results of the study that the highest paragraphs in terms of the degree of approval of the promotion field were in the paragraphs on the topics of packaging some products in large size to make the consumer fancy a large volume of goods, and the declaration of information with insufficient information, and raise the concerns and concern of the consumer through the commercial advertisement to buy it, And the retailer does not provide sufficient information about alternative goods to direct the consumer to a specific option.

It is clear from the results of the study that the highest paragraphs in terms of the degree of response in the distribution are the paragraphs that relate to the topics of the retailer put a high price on the commodity on the pretext of bringing them from far away. , The retailer put low-quality items at a high price because they are sold in high-end stores, the retailer sheds a lot of light on some goods to look attractive and it is not, and the retailer presents the goods in a way that suggests luxury and is not. It is clear from the results of the study that the paragraphs that received the highest response in respect of the field of ethics of the Islamic factor were related to topics such as theft or taking money from customers unlawfully, fraud and deception and lying of any kind and with any party, and to maintain the safety and health of employees and the community and customers, Information not available to the public for gains from trade. 
It is clear from the results of the study that the areas of price, promotion and goods have received a low degree of response in the overall degree, while the areas of distribution and ethics of Islamic work has received a high response rate, and it is clear to the researcher that the reason these low averages to the nature of the fact that the retailer Can work with sufficient flexibility to make a profit, while the flexibility of the retailer in the areas of commodity pricing, promotion and commodity is considered low, and in some ways it can maneuver more in order to maximize profits, which is contrary to the ethics of Islamic work significantly. The results of the study indicate that there is a statistically significant correlation between the total score of the retail trade in Palestine in terms of the commodity, price, promotion, distribution and ethics of Islamic work. The results of the study show that the ethics of Islamic work explain only $13 \%$ of the retail practices in Palestine and the Islamic work ethic, where the coefficient of correlation (0.36) and the adjusted interpretation factor (0.13).

\section{Recommendations}

Based on the results of the study, the researcher made the following recommendations:

1: The retailer must abide by the fact that the information shown on the cover of the item is clear and accurate, and not to tamper with the validity of the commodity and show the country of origin of the commodity.

2: The retailer must refrain from high price practices for some goods to make the consumer fancy that they are of high quality, not to reduce the price of goods that are about to expire, and not to declare the price of the commodity to be higher than the real price.

3: The retailer should refrain from resorting to promotional methods such as wrapping some products in large size to make the consumer fancy a large size product, raising consumer concerns and concerns through commercial advertising to push him to buy his particular items. The retailer does not provide enough information about alternative goods to guide the consumer To a specific option.

4: The retailer should refrain from increasing the prices of some goods, claiming that the price is higher than the source. The retailer has placed low quality goods at a high price, being sold in high-end stores, or manipulating the consumer by shedding strong lighting to look attractive, In a style that is luxurious and not.

5: The retailer must adhere to Islamic business standards in terms of avoiding theft or taking money from customers unlawfully, cheating, deceit and lying, maintaining the safety and health of employees, community and customers, and honesty in presenting information for gains from trade.

\section{References}

Abdeen, M. (2010). The Degree of Ethical Commitment of Palestinian Secondary School Teachers and Teachers from the Perspectives of Teachers and Teachers, Journal of Science, Vol. 6, No. 3, pp. 203217.

Abdullah, K., \& Ismail, A. M. (2010). Compliance to Islamic marketing practices among businesses in Malaysia. Journal of Islamic Marketing, 1(3), 286-297.

Al-Aidaros, A., Shamsudin, F. \& Idris, K. M. (2013). Ethics and Ethical Theories from an Islamic Perspective. International Journal of Islamic Thought 4.

Ali, A.J, \& Owaihan, A.A. (2008). Islamic Work Ethic: a critical Review. A Cross-Cultural Management: An International Journal 15(1), 5-19.

Ali, A.J. \& Al-Kazemi, A.A., (2007). Islamic Work Ethic in Kuwait.Cross Cultural Management: An International Journal 14(2), 93-104.

Arafa, S. S. (2010). Retail Market Management, Dar Al Raya Publishing \& Distribution, Amman, Jordan.

Beekun, R. \& Badawi, J.A. (2005). Balancing Ethical Responsibility among Multiple Organizational Stakeholders: The Islamic Perspective. Journal of Business Ethics 60, 131-145.

Bin Salahudin, S. N., Binti Baharuddin, S. S., Abdullah, M. S., \& Osman, A. (2016). The effect of islamic work ethics on organizational commitment. Procedia Economics and Finance, 35, 582-590. 
Diddi, S., \& Niehm, L. S. (2016). Corporate Social Responsibility in the Retail Apparel Context: Exploring Consumers' Personal and Normative Influences on Patronage Intentions. Journal of Marketing Channels, 23(1-2), 60-76.

Hashi, A. A. (2011). Islamic Ethics: An Outline of its Principles and Scope. Revelation and Science 1(3), 122-130.

Jaros, S. (2007). Meyer and Allen Model of Organizational Commitment: Measurement Issues. The Icfai Journal of Organization Behavior 6(4), 7- 25

Kaliffa, A. S. (2003). The Multidimensional Nature and Purpose of Business in Islam. The Islamic Perspective Journal 7, 1-25.

Khatib, F. S. (2012). Factors Affecting the Selection of Major Commercial Complexes from the Point of View of the Jordanian Consumer, Volume 5, N..(1)

Nematollahi, M., Hosseini-Motlagh, S. M., \& Heydari, J. (2017). Coordination of social responsibility and order quantity in a two-echelon supply chain: A collaborative decision-making perspective. International Journal of Production Economics, 184, 107-121.

Obaid, J. M. (2006). Employee preparation, training, competencies. 1, Amman: Dar Safa for Publishing and Distribution Jordan.

Obeidat, M. I. (2011). Retailing (Concept \& Practice), Dar Wael, Amman, Jordan.

Othman, A. S., Rahman, N.K., Malek, Z., \& Osman, A. R., (2004). Organizational Commitment and Work Ethics: An empirical assessment in a Malaysian context

Rashid, A. H. \& Al-Hayadi, M. (2012). Book of Ethics of the Mission, Amman, Jordan.

Razalan, D. M., Razalan, D. M., Bickle, M. C., Bickle, M. C., Park, J., Park, J. \& Brosdahl, D. (2017). Local retailers' perspectives on social responsibility. International Journal of Retail \& Distribution Management, 45(2), 211-226.

Sodhi, M. S., \& Tang, C. S. (2017). Social responsibility in supply chains. In Sustainable Supply Chains (pp. 465-483). Springer International Publishing.

Suzuki, Y., (2014). Islamic Economics Ethics and Japanese Traditional Business Ethics. Ritsumeikan International Affairs 12, 83-100

Taher, M., Mansour Al - G., Saleh, M. M. \& Al - Ameri., (2010). Social and Business Ethics, Business and Society, 2010.

Tufail, M., Anum., Shahzad, S. \& Jehangir. (2018). Stressors, Organization Citizenship Behavior and Islamic Work Ethics. Journal of Business and Tourism, 4(1), 81-96.

Tufail, M., Shahzad, K., Gul, A., \& Khan, K. (2017). The Impact of Challenge and Hindrance Stressors on Job Satisfaction: Moderating Role of Islamic Work Ethics. Journal of Islamic Business and management, 7(1), 100-113.

Yaken, (2006). What is the Meaning of My Belong to Islam? Beirut: Darul Al-Ressalh Publication.

Yesil, S., Sekkeli, Z. H., \& Dogan, O. (2012). An Investigation into the Implications of Islamic Work Ethic (IWE) in the Workplace. Journal of Economics and Behavioral Studies, 4(11), 612.

Yousef, D. A. (2001). Islamic work ethic-A moderator between organizational commitment and job satisfaction in a cross-cultural context. Personnel Review 30(2), 152-165. 